\title{
Techniques of Motivation, Compensation, and Leadership on Employee's Performance
}

\author{
Evi Husniati Sya'idah* \\ Faculty of Health Sciences \\ Kadiri University, Indonesia. \\ evihusniati@unik-kediri.ac.id
}

\author{
Tontowi Jauhari \\ Faculty of Health Sciences \\ Kadiri University,Indonesia. \\ tontowi@unik-kediri.ac.id \\ Nindi Vaulia \\ Faculty of Health Sciences \\ Kadiri University, Indonesia. \\ Nindi.vaulia@unik-kediri.ac.id
}

\author{
Jatmiko \\ Faculty of Health Sciences \\ Kadiri University,Indonesia. \\ Jatmiko@unik-kediri.ac.id
}

\begin{abstract}
For the sake of the company, managing employees is not easy since it involves various elements, such as employee, leader, stakeholder, and system of the company. It is the domestic vendor of the motorcycle spare part, PT. Zunagawa must be faced so many issues related to human resources and its management. That is why this research is aimed at knowing the effect of motivation, compensation, and leadership on the performance of employees of PT Zunagawa in Blitar. A descriptive quantitative method is employed in this research. The population of this research is all employees in Blitar, which is 30 persons. Then, it is taken 30 employees as the sample of this research. Techniques of data collection used in this research are questionnaires, interview, and documentation. The method of data analysis uses multiple linear regression. Thus, the results of the research show that: (1) simultaneously, compensation and leadership have a significant effect on employees' performance; (2) motivation, compensation, and leadership variable have a partial impact on employees' performance; (3) the most dominant variable among others is motivation.
\end{abstract}

Keywords: compensation, employee's performance, leadership, and motivation

\section{INTRODUCTION}

The positive synergy between human resources and the company becomes a crucial thing in maintaining the continuity of life of a business. The success of an institution or company in achieving its goal is not detached from the human resources owned, because it is the human resources that will organize and manage other resources that the Organization has to help and realize the objectives of the Organization itself. Good companies can be seen from the success of managing their human resources. For the company, managing human resources is not easy because it involves elements in it, such as employees, leaders, stakeholders, and a system that exists within the company. The network owned by the company will not be beneficial to the company itself if useful human resources do not support it. Human Resources is a very important thing for the company, indeed. The role of human resources is manifested in the optimal performance of the employees within the company.
[1] Expressed the performance of employees is the result of work in quality and quantity achieved by a person in carrying out his duties under the responsibilities given. The employee's performance level may have increased or decreased, which is an organizational task to anticipate the decline. [2] suggests that in maintaining and enhancing employee performance, employees can evaluate performance and a series of improvements. Meanwhile,[3] said that employee performance could be influenced by several factors, including motivation and work environment. The other factors include compensation and leadership styles that also have a significant impact on the performance of employees in a company.

[4] stated that with good employee performance, the company is expected to be able to compete with other companies so that it can be recognized that the company has quality performance. A fact in the workforce, the cause of declining employee performance is due to decreased motivation. The internal factor becomes a sort of classic problem in almost all companies that do not have completion. The motivation to be reviewed from science management is a function or tool that is closely related to humans as the mobilizer of people to be able to perform organizational activities. For corporate leaders, management activities are essential in improving organizational performance. The activities undertaken by the subordinates can support the achievement of objectives effectively and efficiently. Each leader always tries to carry out motivation to his subordinates, although it always has obstacles, considering that people have different desires and needs. There are many opinions from researchers or writers about the definition of motivation; among others, [5] expressed that motivation as giving driving power that creates the excitement of one's work, so they want to cooperate, Works effectively, and integrates with all the efforts to achieve satisfaction. Motivation will give a great sense of a person's effort, strive, or work hard to achieve his needs. Conversely, a person with low motivation will never reach a result beyond their motivating power. Besides, compensation for employees ' work should also be taken seriously by the policymakers in the company. 
[6] Compensation is the total of all gifts given by the Organization to employees in return for their services. Furthermore, compensation has an important impact on employees to trigger employee performance so that they can always be at the highest level in accordance with individual abilities [7]. Compensation is a sensitive issue since being pusher in order to make someone work also affects the morale and labor discipline.[8]said that compensation, in fact, was able to have a direct impact on employee performance. Therefore, every company/organization should be able to provide balanced compensation with labor-borne workloads. There are many definitions expressed by researchers or writers, one of which is [9] that defines compensation as /reward is given by the company to the employees because they have contributed their energy and mind for the development of the company in order to achieve the objectives that have been established.

Meanwhile, leadership is also an important part of the Organization's progress. [10]stated that the first factor identified as influencing employee performance is leadership. [2] expressed leadership style is the behavior of a leader who concerns his abilities in leading. Employees need a leader because of limitations and advantages in the conduct and work. [11] Leadership is essentially something inherent in a leader in the form of a certain character, such as personality, ability, and capacity (capability). Leadership is also a series of leader activities (activity) that cannot be separated by the position and style or behavior of the leader itself. Leadership is the process of interrelationships or interactions between leaders, followers, and situations. Therefore, [12] says that a good leader can motivate employees to improve their performance and commitment to the company. [13]stated that employee performance is the quality and quantity of work achieved by an employee in carrying out his duties according to the responsibilities given to him. Employee performance is influenced by ability, working setting, and motivation. Creativity cannot be instituted without the involvement of employees[14].

In this research, we try to analyze how much the influence of motivation, compensation, and leadership style to the performance of PT. Zunagawa employees in Blitar. As the company's national vehicle parts provider, PT. Zunagawa must be faced with problems that are closely related to human resources and management. Moreover, at present, PT. Zunagawa has already employed more than 200 people in all branches throughout Indonesia. As for in Blitra, the company hires 30 employees from the manager of the area, marketing, administration, delivery of goods, up to the warehouse keeper. With the description, researchers hope to find interesting facts related to the influence of motivation, compensation, and leadership style on the performance of employees in the field of implementation

\section{METHOD}

This research uses quantitative descriptive methods. The population used in this research is all employees of PT Zunagawa in Blitar with samples taken are 30 people who are the permanent employees of PT. Zunagawa in Blitar. Data collection techniques in this research use questionnaire, interviews, and documentation. Meanwhile, the data analysis technique uses multiple linear regression.
Analysis of multiple linear regression models is a quantitative analysis used to prove the research hypothesis. This model was chosen because it wanted to know how much the influence of several variables, namely the motivation variable, the compensation, and the leadership of the employee's performance simultaneously and partially.

Furthermore, in Conducting Data Analysis, Data Analysis Techniques Are Used As Stated By [10] Are Interactive Model, Which Consists Data Reduction, Data Display, And Conclusion, Drawing/Verification.

\section{RESULT AND DISCUSSION}

\section{A. Multiple Linear Regression Analysis}

This study used multiple linear analyses to know the effect of each free variable that is motivation, compensation, and leadership against the variable bound of the employee's performance. Based on the calculation of multiple linear regression between the motivation (X1), Compensation (X2), Leadership (X3), towards the performance of employees (Y) obtained the results shown in table 1:

Table 1 Result of Multiple Linear Regression Analysis Coefficients

\begin{tabular}{|c|c|c|c|c|c|}
\hline \multirow[t]{2}{*}{ Model } & \multicolumn{2}{|c|}{$\begin{array}{l}\text { Unstandardized } \\
\text { Coefficient }\end{array}$} & \multirow{2}{*}{$\begin{array}{c}\text { Standardized } \\
\text { Coefficient }\end{array}$} & \multirow[t]{2}{*}{$\mathbf{T}$} & \multirow[t]{2}{*}{ Sig } \\
\hline & $\mathbf{B}$ & Std. Error & & & \\
\hline $\begin{array}{c}1 \\
\text { (constant) }\end{array}$ & $\begin{array}{c}- \\
10.258\end{array}$ & 0.911 & - & -11.262 & 0.000 \\
\hline $\mathrm{X} 1$ & 0.527 & 0.022 & 0.644 & 23.503 & 0.000 \\
\hline $\mathrm{X} 2$ & 0.490 & 0.028 & 0.477 & 17.461 & 0.000 \\
\hline X3 & 0.509 & 0.028 & 0.503 & 18.339 & 0.000 \\
\hline
\end{tabular}

According to the table, the regression equation is obtained as follows: $\mathrm{Y}=-10,258+0.527 \mathrm{X} 1+0.490 \mathrm{X} 2+0.509 \mathrm{X} 3$

1. Constant (a)-10.258 The constant (a) of-10.258 gives the notion that if motivation, compensation, and leadership style are considered equal to zero, then employee performance has a negative value of-10.258.

2. Coefficient $\mathrm{X} 1=0.527$ If the motivation variable is experiencing a hike. At the same time, the compensation and leadership style is assumed to remain, then the employee's performance will increase by 0.527 , or the motivation affects the employee's performance by $52.7 \%$.

3. Coefficient $\mathrm{X} 2=0.490$ If the compensation variable has increased, while motivation and leadership style is assumed to remain, the employee's performance will increase by 0.490 or compensation affecting the employee's performance by $49 \%$.

4. Coefficient of X3 $=0.509$ If the leadership variable increases, while motivation and compensation are assumed to remain, the employee's performance will increase by 0.509 or the leadership affects the employee's performance of $50.9 \%$ 


\section{B. Simultaneous Test}

The simultaneous test is to prove the hypothesis about the significant influence between the independent variables, including the motivation, compensation, and leadership and dependent variable that is employee's performance, through the calculation of the simultaneous test (F-test) that shown in table 2

Tabel 2 Uji F

Anova
\begin{tabular}{|c|l|c|c|c|c|}
\hline Model & $\begin{array}{l}\text { Sum of } \\
\text { Square }\end{array}$ & df & $\begin{array}{c}\text { Mean } \\
\text { Square }\end{array}$ & f & Sig \\
\hline Regresion & 84.300 & 3 & 28.100 & 438.700 & 0.000 \\
\hline
\end{tabular}

From table 2, it proved a hypothesis that there was a significant influence of the independent variables that included motivational, compensation, and leadership on the dependent variable that is employee's performance. It is shown by an $\mathrm{F}$ count of 438,700 and its significance $=$ 0.000 .

Based on the results of the F-test, it is 438.700 with a significance level of $<0.05$, so $\mathrm{Ha}$ is accepted. Motivation, compensation, and leadership jointly affect employee performance.

From the results of this study, the motivational variables can significantly influence the employee's performance, which, based on the calculation of multiple linear regression, demonstrated a level of motivational influence on employees ' understanding of $52.7 \%$. This is the most dominant variable in its impact on employee performance compared to other variables. Motivation is the most significant element for all Organization private or a public zone. Motivation play a significant role for the accomplishment of any organization. The term motivation is basically derived from the word motive [15]. It is in line with research conducted [16], stating that motivation has a positive impact on employee performance. Furthermore, [17] says that there is a positive influence from extrinsic motivation to employee performance, but the absence of positive influence from intrinsic motivation to employee performance.

On the other hand, compensation for employees is also a factor that affects the performance of employees. Although in this research, the calculated results of variable compensation (49\%) indicated no higher than the motivation variable. As with the motivation variable, the Organization's desire to improve employee performance can be done through compensation. It is supported by the research results of [18], which say a strong link between compensation and reward with employee performance. Meanwhile, [19]also expressed the same thing in his research that compensation can be classified as something good and can improve the satisfaction and performance of employees in a company. Thus, in other words, with the measured compensation, a company can have a positive impact on the performance of employees.
Similarly, the leadership variables, which in this study became the second deciding factor $(51 \%)$ in terms of an effort to improve the employee performance within the company. Of course, this leadership variable can also be used to influence performance through policy changes that may be conducted by leaders so that employees have a positive response to the policy that is considered fair and improve the welfare of employees in the company. This fact is also supported by a research result of [20], which says that only transformational and supportive leaders can improve employee performance. Meanwhile, [21] revealed that there is a very strong relationship between transformational leadership and employee performance results. However, laissez-feire style leadership demonstrates the negative relationship between leadership and employee performance in the effectiveness and satisfaction of the employees.

\section{CONCLUSION}

Based on data analysis and discussion, it can be concluded: a) Motivation, compensation, and leadership jointly affect the performance of employees; b) Variable motivation, compensation, and leadership have a partial impact on employee's performance; c) Based on the testing table of the regression coefficient, the most dominant effect on the employee's performance is the variable motivation. Eventually, this study is highly contributed to PT Zunugawa in conducting policy correlating with employees' motivation. Furthermore, this study will give a beneficial contribution to other researchers in conducting further research.

\section{ACKNOWLEDGMENT}

The researcher wants to acknowledge Kadiri University, especially the Health Science Faculty, for giving a chance for doing the research and composing the report.

\section{REFERENCES}

[1] A. P. Mangkunegara, Corporate Human Resources Management, 6th ed. Bandung: PT. Remaja Rosdakarya, 2005.

[2] S. Mardijanto, "The Effect of Compensation and Leadership Style on The Performance of Employees of Husada Ambulu Jember Main Hospital," JRMB, vol. 10, pp. 123-133, 2015.

[3] N. R. Kurniasih, "The Effect of Motivation and Work Environment on The Performance of Employees of Banjar Negara Islamic Hospital," Manag. Anal. J., vol. 1, no. 3, 2014.

[4] . R. H. and Heryanto, "the Effect of Motivation and Compensation on Employee Performance With Work Satisfaction As Intervening (Case Study in the Technical Department of Pt Semen Padang)," Arch. Bus. Res., vol. 7, no. 11, pp. 78-90, 2019, doi: 10.14738/abr.711.6892.

[5] M. Hasibuan, Organization and Basic Motivation for Productivity Improvement. Bumi Aksara, 2014.

[6] B. E. Purnamasari and R. H. Tridayanti, "Analysis of Influence of Compensation and Leadership Style To Employee Performance PT. Feva Indonesia," Quant. Econ. Manag. Stud., vol. 1, no. 1, 2020, doi: 
10.35877/454ri.qems1182.

[7] A. Asriani, D. Lorensa, F. Saputri, and T. Hidayati, "the Effect of Compensation and Motivation To Employee Performance," Int. J. Econ. Bus. Account. Res., vol. 4, no. 01, pp. 166-172, 2020.

[8] M. Uwiyeze, "Influence of compensation practices on employee performance of tea companies in rwanda: a case study of rwanda mountain tea.," Eur. J. Bus. Soc. Sci., vol. 6, no. 06, pp. 160-167, 2017.

[9] S. Siswanto, Indonesian Workforce Management Adiministrative and Operational Approach, Pertama. Jakarta: Bumi Aksara, 2003.

[10] N. Arisa, S. Joko, and F. R. Uchyani, "RJOAS," Russ. J. Agric. Socio-Economic Sci., vol. 9, pp. 37-51, 2018, doi: https://doi.org/10.18551/rjoas.2018 - 09.03.

[11] Wahjosumidjo, Leadership and Motivation. Jakarta: Ghalia Indonesia, 1987.

[12] D. Nawoseing and J. Roussel, "Influence of Leadership Styles on Employees' Performance : A Study of Turkana," vol. 8, no. 7, pp. 82-98, 2017.

[13] Nazwirman Nazwirman, "Analysis of Employee Performance: A Case Study in Port Corporation," J. Organ. dan Manaj., vol. 15, no. 1, pp. 24-35, 2019, doi: 10.33830/jom.v15i1.7.2019.

[14] C. H. Liu, "The processes of social capital and employee creativity: Empirical evidence from intraorganizational networks," International Journal of Human Resource Management, vol. 24, no. 20. Taylor \& Francis, pp. 38863902, 2013, doi: 10.1080/09585192.2013.781519.

[15] A. MuseAliGeelmaale, "Impact of Employee Motivation on Organizational Performance.," Int. J. Adv. Res., vol. 7, no. 10, pp. 166-172, 2019, doi: 10.21474/ijar01/9818.

[16] A. Ali, L. Z. Bin, and Z. Ali, "The Impact of Motivation on the Employee Performance and Job Satisfaction in IT Park ( Software House ) Sector of Peshawar , Pakistan," vol. 6, no. 9, pp. 297-310, 2016, doi: 10.6007/IJARBSS/v6-i9/2311.

[17] U. S. Muogbo, "The Influence of Motivation on Employees' Performance: A Study of Some Selected Firms in Anambra State," AFRREV IJAH, vol. 2, no. 7, pp. 134-151, 2013.

[18] S. W. Njoroge and J. Kwasira, "Influence of Compensation and Reward on Performance of Employees at Nakuru County Government," vol. 17, no. 11, pp. 8793, 2015, doi: 10.9790/487X-171118793.

[19] P. S. Darma, A. S. Supriyanto, U. Islam, N. Maulana, M. Ibrahim, and S. Leadership, "THE EFFECT OF COMPENSATION ON SATISFACTION AND EMPLOYEES," no. February, 2018.

[20] W. Lor, "THE INFLUENCE OF LEADERSHIP ON EMPLOYEE PERFROMANCE AMONG JEWELLERY ARTISANS IN MALAYSIA," vol. 5, no. 1, pp. 14-33, 2017.

[21] M. Asrar-ul-haq and K. P. Kuchinke, "Impact of leadership styles on employees' attitude towards their leader and performance: Empirical evidence from Pakistani banks," Futur. Bus. J., vol. 2, no. 1, pp. 54-64, 2016, doi: 10.1016/j.fbj.2016.05.002. 